\title{
Introduction to A Research Agenda for Border Studies
}

\section{James W. Scott}

It is not an easy task to suggest new research agendas for a field of study that has been in a state of constant flux for close to three decades. Border studies has emerged as a multidisciplinary and even post-disciplinary research area, mirroring the complex transformations that have visited global society. Despite the powerful positivist urge that still exists within the social sciences, it has become virtually impossible to disentangle political, social, economic, technological, cultural and psychological processes in understanding how the world works. Border scholars realize this because borders, understood politically and socially, in fact connect these different processes in space, in time, and at the level of everyday life. A considerable body of literature, including a number of handbooks and anthologies, already gives ample evidence of a research field that has freed itself from the assumptions of state-centred geography and constraints of context-free empiricism. One need only review the contents of collections such as those edited by Wastl-Walter (2011), Wilson and Donnan (2012), Parker and Vaughan-Williams (2012), Wassenberg and Reitel (2020) and others to realize that there has been a marked shift towards the investigation of border-making in diverse socio-spatial contexts and geographical scales. This has also encouraged a shift towards investigating the social consequences of multifaceted processes of border-making (Haselsberger 2014).

Developing a research agenda is also complicated by the fact that border studies reflect the impacts of globalization. For one thing, globalization has created a plethora of new borders despite attempts to integrate continental and regional economies. That globalizer par excellence, the internet, has, for example, provided a ubiquitous platform for everyday border-making narratives and practices - with both positive and negative consequences. If globalization can be understood to encompass fundamental reframings of social, political, economic and cultural spaces, contemporary border research has certainly contributed to their contextual and critical analysis. In doing so border studies has also made considerable progress in breaking down divisions 
between discrete disciplinary approaches within border research (Scott 2018). As a research field, border studies now encompasses a wide range of disciplines besides social geography: political science, sociology, anthropology, history, international law as well as the humanities - notably art, media studies and philosophy.

Various sources, such as key academic debates, political discourses, ethnographic research, media representations and shifting cultural understandings of the construction of national borders have contributed to conceptual change in border studies. These conceptual shifts have reflected the often traumatic experiences of border-crossing and border-crossers (Schimanski 2019; Velasco Ortiz and Contreras 2014) but they have also received major impetus from life at borders itself. As will be discussed below, recognition of the richness of cultural spaces at and around borders, such as in the US-Mexican case, has had a transformative impact on border studies. As is the case with the humanities and social sciences, border studies has been deeply influenced by the constructivist turn, the linguistic turn, post-structuralism, social activism and numerous epistemic perspectives that challenge status quo (e.g. Eurocentric, state-centric, male-centric) thinking. Moreover, I would argue that borders scholars now take more seriously the interrelatedness of previous thinking about the investigation and interpreting of borders. In the contemporary practice of border studies, literature and art tell us as much about borders, borderlands and border-crossings as do ethnographic or historical investigations. It is precisely disruptive forces of change - whether real or imagined - that drive home the main argument of border studies: that borders are in a constant process of confirmation, contestation, transformation and re-confirmation.

Why then this research agenda and how to define it? Certainly not as a presumptuous or 'revolutionary' jump to some new level of conceptualization given the depth of the existing research background. Instead, the objective of this research agenda is to elaborate research perspectives that build on and develop this rich state of the art. More specifically, it reflects the continued salience of asking questions related to the why and how of borders. In developing this collection, the authors have in their own ways chosen research perspectives that connect everyday processes and experiences of border-making to the wider social world. Their contributions reinforce the assumption that borders are not given, but emerge through socio-political and cultural border-making processes (i.e. bordering) that take place within society. Borders are not, for example, mere independent variables in the analysis of political processes, they are co-constitutive of political agency. 
One recurring motif of this collection is that the power of borders emerges not only from their institutional and legal nature but also from their symbolic and identity-forming significance. If nothing else, this research agenda seeks to uncover links between different levels of border-making, from the political to the cognitive. As part of this, relating political understandings of borders to their ontological importance, also in terms of border ethics, would represent a possible way forward. Certainly, one objection that could be raised at this point is that we are not at all talking about the same kinds of borders and are, in fact, confusing different things. Political borders serve as objective markers of sovereignty, authority and police power over territory while socio-cultural borders are much more subjective markers of identity. We would however argue that most borders scholars reject this view. The highly symbolic acts of closing national borders during the Covid-19 pandemic, of building a formidable wall on the US-Mexican border or of sealing off the Hungarian-Serbian border to prevent undocumented refugees from entering the EU are just a few examples where political rationale, fear and affect coalesce.

In opening our discussion on research agendas, this introductory chapter serves two purposes: it will provide an overview of the book and the various themes that the contributors have developed. Before proceeding to the overview, the introduction will also foreground discussion by broadly focusing on areas where border studies seem to be heading. Firstly, there is the question of the broader political salience of borders as reflected in border studies research. Secondly, we suggest that through development of the bordering paradigm, border studies is increasingly linking ontological and ethical questions to processes of border-making. These perspectives are obviously interlinked, differing mainly in thematic focus. Taken together, they address the question as to how everyday bordering practices and discourses can be productively linked to different aspects of social relations (for example, with regard to political processes, socio-cultural change, economic development, etc.).

As the above indicates, the research field of border studies is an immense source of inspiration. As a result, this volume can only be a small but hopefully salient contribution to its development. Indeed, the limitations of this book are given by its relative brevity and the fact that the authors did not attempt to compile a comprehensive survey of the state of the art, nor would covering all areas of possible development have been within the volume's remit or scope. What we are suggesting is not the definitive research agenda but a number of research perspectives that emerge from the work of individual scholars who are contributing to conceptual development in border studies. We therefore recognize that we might have excluded a number of important issues from our discussion. However, in addressing a number of cross-cutting themes, several 
of which have received relatively little research attention, we believe that this collection is highly relevant to the wider debate.

\section{Borders: political arenas, sites of contestation, spaces of possibility}

Borders are inherently political and research engagement with the political salience of borders has been a major constant in the development of the research field. Borders are at the heart of territorial sovereignty and anything associated with a state border or the crossing thereof is subject to potential politicization. And yet, from the perspective of border studies, change in the ways borders work and how we think about borders is ubiquitous and deep. To begin with, the contemporary state of debate reflects a rather radical shift away from reifying national borders as expressions of popular sovereignty, political recognition and freedom from externally imposed constraints. Instead, borders are often subject to critical re-readings as instruments of power (understood in negative terms), selection, exclusion and neoliberal exploitation (Loong 2019; Newman 2003; Zeveleva 2017). Borders, moreover, are violent (Jones and Johnson 2016) and reflect the 'global disorder' that has laid bare the frailties of existing political, economic and environmental practices. There is also a strong post-national agenda in border studies that addresses the possibility of political agency beyond nationally framed thinking and constraints (Laine 2016; Rumford 2014). As an example, border politics can also be framed as a transcendence of particularism and territorial anxieties, for example to the extent that it promotes conflict management (McCall 2014) and cross-border cooperation (Medeiros 2018) and/or represents an economic and political resource (Sohn 2016).

While border politics, understood in the broadest sense of the term, drives much present research endeavour (see Staudt 2017; Vaughan-Williams 2009), conditions of linearity and territorial fixity have given way to more fluid understandings of where borders are located and the functions they perform. The territorial border itself is now widely understood as part of a much larger complex of regimes, practices and narratives that perform various border-making functions. In contemporary conceptualizations, it is not only specific 'lines of control' but assemblages and different political configurations of borders that are significant. Borders have become mobile (Walters 2015), networked (Popescu 2011) and extraterritorial (Casas-Cortes et al. 2016) as part of managing mobility and migration flows. Moreover, state borders are being reconfigured through their diffusion within society and through the 
agency of multi-actor networks that include, among others, the state, local governments, private firms, humanitarian organizations and international organizations (Pallister-Wilkins 2017). Within this resulting 'borderscape', border politics reveals itself in the mutual entanglement of humanitarianism and the securitization of migration (Dijstelbloem and van der Veer 2019).

Borders are also being reconfigured by the politics of pandemics. As this research agenda was being edited during early 2020, the Covid-19 virus emerged as a major challenge to societies and health systems around the globe. As part of the attempts to control its spread and crushing impact, national and in some cases internal borders were subject to stricter controls and even complete closure. While the efficacy of such measures can be questioned, the symbolic nature of closing the border evoked the sense that something forceful and authoritative was being done. Even the European Union which prides itself on open internal borders did not shy away from suspending the Schengen Area's freedom of movement in the face of calls for decisive action. At the same time, social distancing, working from home, travel bans, the cordoning off of public spaces, and the unequally distributed impacts of the pandemic reinforced a sense of bordering and ordering at the level of everyday life. As daunting as the challenges of managing pandemics are, more pervasive and long-term in their societal impacts are the border politics of selectively walling, enclosing, restricting, separating, (im)mobilizing and securitizing people and things (Vallet 2018). Here, borders are in evidence as institutions and processes that profoundly affect everyday life and that condition that which is most central to social life - a sense of identity.

In his compelling book on border politics, Matthew Longo (2018, p. xv) has characterized the power of borders in terms of reducing individuals to subjects bereft of all personal traits except for documents that give proof of belonging to a specific community or state. For Longo, borders are:

sites of identification where the rudimentary aspects of our political and social identities are called into question, scrutinized and judged; where we are forced to reconcile ourselves as citizens or co-nationals and understand the privileges and obligations of those commitments.

Understood in these terms, borders are inescapably biopolitical, serving to emphasize belonging, difference and the privilege of the state to exclude. Moreover, with increasing securitization, borders have almost become inseparable from questions of xenophobia, exclusion and inequality (Günay and Witjes 2017). In tandem with the securitizing discourses that stigmatize mobility and migration, political pressure has increased for more formidable 
and militarized borders in order to defend national cultures (Vasilev 2015), even at the risk of reducing cross-border mobility for everyday citizens and curtailing democratic rights (Jones and Johnson 2016). Resurgent populism complicates the picture even more as it hampers measured debate regarding the need for border openness. While populism has become a major political post-millennial force more generally, it is visibly on display in Central and Eastern Europe where border politics involves a serious contestation of 'liberal European' values. Anna Krasteva (2020, pp. 694-695) writes, for example, that in the case of Central and Eastern Europe, we find "extensive production of and investment in" ethnic, religious, symbolic, cultural, national, European boundaries as well as narratives that mobilize the anti-elitist notion that the EU "subverts and erodes national sovereignty", while identitary power "unites and protects national societies from multiplying enemies that constantly change their guises: the EU as 'gays', Islamic fundamentalists disguised as refugees".

One way to read the state of debate is that borders have become complex socio-political arenas where issues related to identity, security and mobility, among others, are enacted and represented. There are, in other words, a multitude of contexts and spaces that count as borders. State borders vie for research attention along with processes of everyday social and cultural bordering. Moreover, the border studies debate reflects the understanding that formal state and informal everyday borders are closely linked. One need look no further than the aforementioned example of Trump's border wall with Mexico, exploited as much as a culturally charged symbol of nationalism and revanchist nativism as a management 'solution' for undocumented migration. Within the context of the EU's external (Mediterranean) borders, Vaughan-Williams and Pisani (2020) describe border politics as a continuum of border control and migrant agency - it is not merely a question of border management agencies responding to the challenge of 'refugee crises'. While they remain important reference points in the debate, state borders do not exist as mere objective facts; the social realities they condition are very much dependent upon how and by whom they are perceived, experienced, negotiated and exploited.

Consequently, the political uses of borders continue to beg questions regarding why and how border-making proceeds. This is echoed in Paasi's (2012) suggestion that uncovering the complex political and social modalities of bordering processes can transcend relational/territorial divides and other limitations borders might impose on our thinking. In 2009, Parker, Vaughan-Williams et al. defined a research agenda for critical border studies that sought to do just this; in that collection of perspectives and its further elaboration as a special issue of Geopolitics (2012), the central aim was to pursue border questions in terms of non-territorial epistemologies and methodologies, given the obvious 
diffusion of borders into society. This agenda was inclusive and included, among others, phenomenological understandings of borders as something experienced, crossed, lived at and negotiated on an everyday basis. As Parker and Vaughan-Williams et al. (2009, p. 586) warned, without problematizing modernist and 'territorialist' Western geopolitical imaginations, "the study of borders [would] continue to lag behind the increasing spatial and temporal sophistication of bordering practices in global politics".

Looking back on the development of borders studies we can confidently state that such concerns were largely unfounded. As a result, much of what borders scholars do is to examine the different ways in which borders exist socially, spatially and temporally as part of human existence. Ontological questions are now writ large and have even become mainstreamed in the (not only critical) border studies literature. One major ontological view on borders and how/ where they exist, for example, is the topological perspective in which borders are diffused throughout networked space as practices, discourses, technologies, etc. (Awan 2016; Mezzadra and Neilson 2012). Here, borders can serve the purpose of everyday ordering and sorting (e.g. securitization) of people as well. The 'humanitarian border' is thus another example of emerging research where topological ontologies are productively elaborated (Kallio et al. 2019). The ongoing challenge is to link the different ways in which borders manifest themselves to their concrete political significance and societal impacts.

\section{Consequences of bordering: linking the political with the everyday}

Since the 2002 appearance of Henk van Houtum's and Ton van Naerssen's agenda-setting essay 'Bordering, Ordering and Othering', border studies has dedicated considerable energy towards exploring different ways in which borders are produced socially. Instead of privileging linearity and functionality, contemporary border studies recognizes the fluid and changing nature of borders, their increasing sophistication, and the complexity of border-making processes by different agents (Laine 2016; Laine and Casaglia 2017). This has opened up possibilities for investigating socio-political border-making and bordering practices that take place within society. With bordering, a conceptual transition has also taken place from seeing the border as a physical and often static geographic outcome of socio-spatial dynamics to a context in which the borders are themselves understood as dynamic functional processes. At its most basic, the process of bordering can be defined as the everyday construction of borders, for example through political discourses and institutions, 
media representations, school textbooks, stereotypes and everyday forms of transnationalism. Bordering, as a socio-spatial practice, plays an important role in shaping human territoriality and political maps - every social and regional group has an image of its own territory and boundaries.

'Bordering' is now a central paradigm within border studies, but one that is in flux. General consequences of the bordering perspective include a highly critical re-evaluation of the relationship between states, societies and the borders they create. Furthermore, the bordering perspective also recognizes the profound psychological significance of social borders (Marsico and Varzi 2015). Clearly, simply assuming that systemic logics of control (governmentality), selection and division (biopolitics), postcolonialism or neoliberalism explain bordering can result in reductionist thinking about something that is highly complex. Borders cannot be separated from the specific contexts that explain their social salience and impact. Instead of deconstruction, borders demand an investigative piecing together of the many elements that explain their significance and the processes that condition bordering practices (see Tsoni 2019). This has, for example, been suggested by Christophe Sohn (2016) who has captured the ontological multiplicity, or heteronomy, of borders with the concept of 'assemblage' in which borders emerge through the many different meanings and practices that are attached to them. Where are borders located? As Anthony Cooper (2015) has suggested, Europe's borders are not necessarily made in Europe according to realist notions of territoriality and sovereignty but that borders of Europe are actively negotiated as well as imagined at many different scales and sites.

One consequence of the bordering paradigm is an increasing appropriation of the borderscapes concept (Brambilla 2015a; Dell'Agnese and Amilhat Szary 2015; Grundy-Warr and Rajaram 2007). Borderscapes are multilocal socio-political arenas that emerge around border(ing) contexts and are thus diffused beyond the physical border. With a borderscapes approach, the realm of high politics is connected with that of communities and individuals who are affected by and negotiate borders and hence it represents a highly promising tool for 're-assembling' border complexity. According to Brambilla (2015b, p. 111) borderscapes express "the (geo)political and epistemic multidimensionality of the border, enabling a productive understanding of the processual, de-territorialized and dispersed nature of borders and their ensuing regimes in the era of globalization and transnational flows". The term borderscape also puts greater emphasis on representations of borders as well as individual and collective practices of border-making which shape political subjectivities in specific situations. Two contrasting examples out of many are Punta Tarifa (Spain) and the island of Lampedusa (Italy). In the first case, migrant presence 
and all references to the area's Islamic past are made invisible as means to highlight 'Europeanness' (Ferrer-Gallardo et al. 2015). The LampedusaInFestival (Brambilla 2015b) achieved the opposite, if only temporarily, namely a space for making migrant presence visible through performative action and cultural expression.

Epistemologically, the borderscapes approach connects border experiences and border-making practices; borderscapes are contexts where cultural appropriations and social contestations become visible via a broad repertory of communicative means and strategies. As Brambilla herself states in an interview, borderscapes consist of spatial practices in the sense of Michel de Certeau (1990), and thus allow for the abandonment of essentialized ideas of political borders and an understanding of contemporary borders "as continually performed and (re)composed by sets of contingent performances revealing their dynamic character" (Brambilla and Pötzsch 2015). And yet, the borderscape is both a reflection and re-appropriation of an existing border context and thus gains social significance as a political project of contestation and site of struggle (Brambilla and Jones 2020).

In terms of critical border studies, the borderscape concept helps relativize highly critical positions that problematize links between social relations and territoriality. In the literature we often find decidedly negative framings of bordering as processes of differentiation inherently linked to exclusionary processes, a negative vision of borders informed by spectres of Fortress Europe, neoliberal economic exploitation, the plight of migrants seeking safety from conflict and a better future and the increased securitization of borders. All of these factors continue to create and reproduce socio-spatial inequalities and as such remain highly salient to the study of borders. However, through the borderscape lens, bordering critique has opened up space for alternative understandings of border-making practices. We are not limited to mere deconstruction and questionings of borders as expressions of exclusion or mechanisms of governmentality, but can also study how and why borders also serve as resources for dialogue, cultural expression and political empowerment (Deiana et al. 2019; Mezzadra and Neilson 2012).

\section{Overview of the research agenda}

It has become widely accepted that "borders are a complicated social phenomenon related to the fundamental basis of the organization of society and human psychology" (Kolossov 2006, p. 606). In the essays that follow, questions will be 
raised that stimulate thinking about borders as something personal yet collective, imposed yet contingent and self-created. The body of this research agenda is divided into three main sections that focus on (1) socio-political borders, (2) the multilocality of borders in society ('borderscapes and beyond') and (3) questions of border ethics. The chapters develop a variety of perspectives regarding possible future research avenues. As this research agenda is neither a reference work nor a compendium of the state of the art, there are of course numerous aspects that cannot be addressed in detail here. Instead, the focus is on individual perspectives that have emerged from research experience. There is also no obvious meta-theoretical commitment expressed here. What the essays in this volume offer are contextual understandings of borders from various standpoints, whereby the reader will discover numerous interconnections between the different texts.

\section{Socio-political borders}

The introduction, which forms Part I of this book, is followed by Part II that explores the continued salience of socio-political borders. The section begins with Anna Casaglia's reflections on border politics and the need for research agendas that link increasing territorial flux, 'de-nationalization' and borders of sovereignty. In her chapter, Anna Casaglia argues that borders are markers of different and various layers of power relations, where tensions between border reinforcement and border-crossing occur continuously. In her estimation, it is necessary to underline the way in which borders simultaneously perform several functions of demarcation and territorialization. In this way, we can think of the border as a mutable, adaptable and malleable political device used to pursue specific goals, for example as technologies for the articulation of control and selective inclusion and exclusion of different kinds of movement and flows. She also reflects on how the control function elicits resistance and that this has also provided impetus for borders studies to engage with borders as 'sites of struggle' in different localities and involving various actors. As part of this, Casaglia elaborates on the increasing embodiment of borders as devices of control by those who cross or try to cross them - policing borders means policing bodies. Within this context, Casaglia suggests that future border studies agendas could redouble efforts towards achieving a better understanding of borders as technologies for the reproduction of inequality. She suggests, in addition, an intersectional approach to theorizing and researching bordering processes through mapping 'geographies of oppression'. For example, the combination of passport nationality and economic considerations indicate how border-crossing is subject to both ascribed and acquired personal characteristics and thus ultimately an intrinsically subjective experience. 
Anna Casaglia's contribution critically reflects a need to question the realpolitik of borders and the 'objective' assumptions of realism more broadly. Border realism is traditionally informed by the reductionist assumption that borders are necessary instruments of securing national unity and territorial integrity. Despite overwhelming evidence that border securitization does not make states more secure, realism remains a dominant narrative. Societies ignore border complexity at their peril especially, as Paul Richardson explains in his chapter, when borders are wilfully narratives as something civilizational or 'hyperreal'. Richardson draws on emerging trends in border studies to explore how spatial imaginaries of sovereignty are instrumental in structuring some of the key debates of our time, including the future of the European Union, responses to humanitarian crises and migrant flows, as well as notions of Great Power status and value spaces. The power of such imaginaries has contributed to a global materialization and proliferation of borders not seen since the end of the Cold War. Richardson also points out rationales and reasons behind a dangerous and destabilizing detachment of representation from reality. We find ourselves in a world of inversions, of expanding networks and connectivity but where sovereignty is represented as ever more absolute, where borders have become the centre of spatial imaginaries, and where 'tradition', imperial legacies, and origin myths are the future. In our times of ontological insecurity and uncertain political authority, the trope of 'taking back control' deflects from the urgent task of remaking and reconceptualizing borders and sovereignty in response to socio-economic and political realities.

Richardson calls for a critical border studies that is adaptive and alert to the rescaling and reshaping of the border that the civilizational turn entails. As Richardson shows, shifts between nationalism and civilization are reconfiguring our everyday socio-spatial and political realities in ways that should worry us indeed. Alongside this exploration of civilizational imaginaries of sovereignty, the chapter also explores the notion of the hyper-border, where the instrumental and pragmatic nature of identity can puncture imaginaries of uncontested national space and immutable borders. It reveals how the fluctuating political authority of the state at its extremities can render national identity as contingent, malleable and instrumental in such borderlands.

In the following chapter, Inocent Moyo addresses the need for renewal in the study of postcolonial borders. One of the central themes in the postcolonial critique of African borders is that coloniality continues to influence the way in which borders are governed but without considering the artificiality of the borders resulting from the 1884 Berlin Congress. This situation is said to have led to social, economic and in some cases, political conflict and generated countless hardships for local populations, particularly those living in border- 
land communities. Moyo agrees that postcolonial critiques and approaches to the study of borders are vital to the extent that they expose vestiges of colonialist thinking and indeed provide a basis for a resistance to colonial perspectives and hegemonies in the study of borders. In his chapter, Moyo argues that there is also a need to move beyond such analyses. He asserts that a postcolonial analysis of borders often overlooks on-the-ground contexts of African border dynamics; frequently, realities of life at borders and the everyday significance of border-crossing are neglected. A case in point is that some so-called postcolonial African states actually punish precolonial and non-postcolonial forms of border interaction. One example is the border between Botswana and Zimbabwe where border-crossing for family, cultural and other reasons has been met by border securitization and politicization in order to emphasize 'the division of the two countries'. A similar case is the tendency to formalize and bureaucratize cross-border trade to the detriment of local communities. As Moyo argues, greater engagement with socio-political borders on the ground and local border practices is needed. This in turn requires a research agenda that does not limit possibilities of borderlands development by treating it, a priori, as a remnant of coloniality and imposed borders.

In the final contribution to this section Christophe Sohn approaches socio-political borders from the assumption that borders represent multifarious resources. Given that refence to borders as resources is in fact relatively recent, Sohn suggests that future research agendas could shift the mainstream border studies focus from investigating national borders as constraints on everyday life to one where the ability of border populations to negotiate borders to their advantage is considered. Such opportunities arise mainly from the capacity of people to cross a border and take advantage of the differences instituted or revealed by it. Focusing attention on the periphery (instead of the centre) and local agency challenges the centrality of state-oriented approaches and sheds light on the capacity of local people to engage with ongoing processes of border-making. Nevertheless, conceiving borders as resources also raises questions, some which are related to Anna Casaglia's critical scrutiny of borders and extended policing practices. Sohn reminds us that in a context of security-led re-bordering and resurgent nationalism, borders are widely mobilized in populist discourses and authoritarian postures that seek to reinforce and legitimize their role in protecting a secure and familiar 'inside' from a dangerous and chaotic 'outside'.

Sohn's intention is to unpack conventional explanations and to propose a new conceptualization that articulates the diversity of practices, politics and ethics at work, and to critically place in the foreground the implications of these changes. The resulting theoretical framework highlights two main 
border opportunity structures and their underlying rationales. An examination of the practices and strategies used to mobilize these opportunity structures makes it then feasible to highlight fundamental changes in the creation of border-related resources and to critically examine the issues at stake. The control over formal border-making processes by private interests - in particular multinational companies - and their exploitation as resources is inducing major changes: it is no longer simply a matter of taking advantage of particular border-related opportunities, but of purposively transforming borders into a sprawling and lucrative business through various processes of neoliberalization. Such a 'businessification' of borders represents a significant modification of how and in whose interests bordering operates, and hence, undoubtedly constitutes a serious societal challenge for (post-) democratic societies. Ultimately, the scope of these transformations underlines the critical potential of the concept of borders as resources and calls for reconsidering its positioning within border studies.

\section{Borderscapes and beyond}

Part III of this volume deals with the consequences of the ontological multiplicity of borders and the significance of border-related practices. In her chapter on urban contexts, Deljana Iossifova focuses our attention on the idea that borders represent the physical communication of socio-spatial difference. They are the symbolic expressions of simultaneous inclusion and exclusion and functions of national, regional, political, or otherwise defined identity. Border phenomena appear across scales and typologies. However, they are usually discussed and examined at the scale of the nation-state. At the scale of the city, borders can divide urban units - and sometimes explicit enclaves - on the basis of their natural environmental limits; their governance and administration; their spatial morphology; their ownership; or socially constructed parameters such as identity. In turn, identity can be dominated by ethnicity, socio-economic status, religious beliefs, place of origin, occupation, political views, age, or even sexual orientation, among many other possible markers. The borders between urban quarters can be blurry, in flux and not physically traceable. They can also be, as in the case of gated communities, clearly defined by fences and walls. Whatever their physical manifestation, they are always multidimensional and socio-material spaces that can be and are shaped by various global and local forces. Iossifova discusses the transferability of border studies concepts to the (intra)urban scale. Within this context she raises the question as to the conceptual and analytical frameworks that can be applied in differentiating between old and new, modern and traditional, rich and poor, planned and organic, formal and informal, permanent and temporary, local and migrant in the city. 
Victor Konrad's contribution is situated at the nexus of psychological, emotive and more formal understandings of borders. He provides an alternative understanding of how belonging engages with borders and territory, going beyond examinations of state-based belonging. Konrad's approach consists of mobilizing the theory of relations of part to whole, and of part to part within the whole - i.e. 'mereotopology'. This theoretical construct derives from both classical and modern philosophical and logical studies and is applied, as it relates to our purposes, in cultural psychology. As Konrad argues, research in both cultural psychology and philosophy supports a science of human liminal constructions, and explores the constant border-crossing in the arena of human development. In border studies, mereotopology promises to help us understand the basis of individual and social becoming that leads to belonging in a territory, and the role of borders in the process of defining both territory and belongingness. Konrad offer a theoretical framework for the study of borders and belonging. The initial step is to explore the promise of mereotopology as a theoretical base. The discussion that follows aims to situate borders, territory, and belonging in a theoretical framework that builds on this base. The discussion draws extensively on evidence of borders and belonging from field research conducted in the Salish Sea region of the North American Pacific coast, the borderlands of China, Myanmar, Laos and Vietnam, the Virgin Islands of the Caribbean, and the Basque Country. A central goal is to define the state of belonging, or belongingness, as it relates to borders. This goal is approached first by examining the components and qualities of belongingness, and then examining how these aspects engage with borders. The final section of the chapter evaluates what this study contributes to the political culture of bounding space and place, and suggests additional research directions in this promising engagement of border studies with philosophy and cultural psychology.

Tuulikki Kurki approaches the possibility of alternative border conceptualizations through 'materialized narratives' which she suggests is a promising area of future border studies development. In her approach, materialized narratives refer to material objects (things) and works of art that relate to various kinds of borders and border-crossings. They also refer to objects that belong to or are prepared by people crossing borders or living in borderlands. The first part of her chapter reviews recent narrative approaches in multidisciplinary border studies and asks, for example, what kinds of information about borders are conveyed through narrative analysis and how the relationship between narratives and borders is understood in these approaches. Kurki's essay then focuses on the question of how borders could be conceptualized through 'materialized narratives' and how the information that they convey could enhance our thinking about borders. Kurki suggests that research ideas could be formulated 
around the theme of everyday objects and coping with borders. Everyday objects and interacting with objects may embody people's strategies to cope with borders, bordering processes and border-crossings, and the consequences they have on people's lives such as displacement or feelings of alienation and exclusion. On the other hand, this line of research may also embody strategies of successful border-crossings where objects become signs of expectations, hope, resilience, and indications of people's changing relationship and adaptation to the environment of border and borderland. Another research agenda that might emerge through the study of border-related objects is the idea of an 'objectscape' in which everyday objects provide a view on the material landscape and materiality of borders in people's lives that is perhaps located in their homes, or in their pockets. These objectscapes could be characterized by artefacts and things linked with non-places, and experiences of transit and solitude, or to feelings of displacement and non-belonging. Objectscapes could also be characterized by fading memories of things lost as well as more abstract questions of materiality linked to well-being, poverty, wealth and the construction and maintenance of difference and exclusion in various borderlands.

In her chapter, Alicia Español elaborates an intriguing study of an iconic borderlands context, that of the cities of Ceuta and Tétouan on the SpanishMoroccan border. Her study is both one of everyday border-making and, at the same time, understanding the border as a process of meaning-making. The aim of her chapter is to suggest research agendas that allow us to more deeply understand the link between border experiences and the ways in which borders are socially constructed. As an example, Español's chapter describes border experiences and practices as captured by the self-narratives of people living at the Spain-Morocco border between Ceuta and Tétuan. From a cultural psychology point of view and focusing on personal meanings, she analyses the border experiences of a group of Moroccan and Spanish men who cross the border to work. The analysis is also centred on border practices which reflect demarcation, differentiation and othering processes, as well as linkaging and connection practices. Español's results show that for both groups the principal significance of the border is to make a living; for example, through crossing over for work Spanish men are able to realize opportunities that are non-existent on their side of the border. Both groups describe a diversity of bordering practices, mainly linked to create a differentiation based on language, nationality or educational background. She concludes that the multiple bordering processes experienced by the interviewees in their social relationships eventually influence their individual sphere, as reflected in their self-making narratives. 


\section{Ethics and borders}

In Part IV of the book, future research agendas are elaborated that more explicitly address questions related to the ethics of borders and bordering. Jussi Laine acknowledges that contemporary border studies has indeed considered ethical issues, primarily those linked to state borders and sovereignty, the securitization of everyday life, discriminatory exploitation of borders, and exclusionary regimes, regulations and policies. However, far from being something absolute, borders are perceived by and affect different people in very different ways. The political dilemmas created by discourses and practices of identitary bordering, for example, present a particularly serious test of collective values, liberal ideas and ethics. As part of this research agenda Laine's chapter seeks to explore the links between borders and ethics more thoroughly with regard to various practices of border-making and the politics of difference. Laine addresses the ethical conundrum by addressing what seem to be inherently contradictory positions, namely balancing calls for freedom of movement with the right to freedom of association and the relative weight that should be assigned to each. Issues regarding what is morally correct proliferate, particularly with regard to travel, migration and openness towards asylum seekers. We find that state commitments to asylum have become increasingly conditional and that instead of solidarity, several governments in Europe and beyond have opted for restrictive regimes, walls and fences as a response. In doing so they undermine moral, legal, philosophical and economic justifications for limiting migration. It would, however, be quite a jump to conclude from this that a world without borders would somehow represent a better solution. Here, Laine refers not only to the ethics of the territorial border per se, but of the entire international system. He does not advocate a borderless world but one that is more generally just. Even if all borders disappeared overnight, this would not address underlying injustices that, for example, force people to emigrate. Borders continue to serve various purposes, yet perhaps more than ever these are unlikely to be the same for everyone. Scholars need to pay more attention to this realization. In terms of research agendas - but also at a much wider societal level - Laine implies work is needed to ground our moral obligation to make borders more permeable not only according to humanitarian principles but also in view of the fact that we are no longer simply part of isolated national communities.

Nick Megoran takes a somewhat different approach to ethical questions. He argues that international borders are not only violent but often deadly: at their most raw they can be understood as techniques of lethal force designed to protect wealth and privilege. It is therefore not surprising that many authors have advocated open borders on various ethical, moral, religious, economic, legal and practical grounds. However, many practical visions of 'borderlessness' 
that have emerged over time have themselves become implicated in different forms of violence. Because of this, Megoran argues that existing radical, liberal or libertarian arguments for 'open borders' are inadequate. As an alternative, he 'tunes in' to the recent revival of anarchist thought in geography and returns to the well-known tradition of Christian anarchism. Two Christian anarchist thinkers in particular provide inspiration: William Stringfellow, whose ethics originate from vocation as calling and Walter Wink, who articulated a political theology of the role and responsibility of archē ('power and authority'). Megoran argues that by conceiving of international borders as a form of archē with a "limited mandate to promote good and restrain evil", a more rigorous and practicable basis for negotiating a more peaceful and cooperative international system might be possible.

\section{Concluding remark}

As this research agenda demonstrates, the processual approach to borders implies that borders are co-constitutive of multifarious border-making and border-crossing practices such as uses of space, narrations of place and political instrumentalization and securitization practices, all of them with ethical consequences. We are again reminded that borders are both makers and carriers of meaning. Bordering practices are not merely social practices through which state-building and territorial consolidation transpire (see, for example, Paasi 1999) but are something more central to everyday life and being-in-the-world. Perhaps one conclusion that can be drawn is that thinking about borders in a reflexive and critical manner requires us to ponder the consequences of living at borders as well as the consequences of our own border-making and border-interpreting practices.

In a critical understanding, the strength of border thinking lies in turning the objectivization of border knowledge on its head. Border thinking, or el pensamiento fronterizo, is most often associated with Gloria Anzaldúa's (1987) iconic exploration into Mexican-American/Chicana identity; in her work, pensamiento fronterizo emerges as an open challenge to foundationalist border narratives and the enduring colonialization of the spirit by the powerful and vindictive. Anzaldúa's vision is a decolonial alternative, informed by personal experience of racism, homophobia, macho culture and intolerance while growing up in South Texas. But this vision also has a wider appeal as the idea of pensamiento fronterizo also suggests a deeply reflective approach to life that emerges from being at the border. Border thinking is a way of seeing the world and social reality from the vantage point of being at social, cultural and politi- 
cal borders, in which diversity, the coexistence of many different social worlds and the daily negotiation of border-crossing rituals, e.g. code-switching, is the norm. Being at the border can also mean having very different places simultaneously as central reference points in everyday life.

It is not a coincidence that iconic borderlands such as the one between the USA and Mexico have become sources of cultural knowledge and vital forces of cultural change. Here we see a reversal of the traditional top-down narrative of borderlands as peripheral backwaters, lawless spaces and civilizational divides. Not only does a rich artistic, literary, culinary culture flourish in the US-Mexico borderlands but influential social and cultural critique has emerged there. We only need to browse through an extensive literature such as the compilations of Benito and Manzanas (2002), Dear and Leclerc (2003), Zúñiga (1999), Kun and Montezemolo (2012) and many others to grasp the wider impact of the borderlands imagination.

Border thinking helps us understand the borders around us, the borders within us, the borders that we constantly make. It also breaks with monological obsessions and suggests that we can undertake a move from a thought-stopping to a thought-propelling consideration of borders as spaces of possibility. As Anzaldúa's own biography reveals, border identities emerge not as binary oppositions but rather as multiple subjectivities that interact in very dynamic spaces. In this way, Anzaldúa's 'new mestiza consciousness' inspires us to think of border-making as a form of disobedient, perhaps radical, freedom and liberation. It is privileged thinking because despite the vulnerability and struggles that underpin being 'at the border', it is way of thinking that provides a space for both self-creation and, more broadly, the disruption of simplistic narratives of difference. In this context, the idea of cosmopolitanism also takes on a rather new meaning. Rather than represent a (Western) universalistic ideal, with border thinking cosmopolitanism becomes part of everyday life, echoing Chris Rumford's (2006, p. 163) suggestion that:

cosmopolitanism is best understood as an orientation to the world which entails the constant negotiation and crossing of borders ... Borders connect the "inner mobility" of our lives with both the multiplicity of communities we may elect to become members of and the cross-cutting tendencies of polities to impose their border regimes on us in ways which compromise our mobilities, freedoms, rights, and even identities.

In closing I would like to venture one final idea related to border thinking as something reflexive but also inspired by a 'parrhesia' with regard to borders and sovereignty. As Anna Casaglia, Jussi Laine and Nick Megoran have highlighted in their chapters, the illusion of national autonomy, along with 
ontological insecurity, is one source of major ethical problems with borders. Two of many reasons for this can be mentioned. At one level, social and economic relations are highly networked across borders and many communities are by definition transnational. One can, for example, point to the vicissitudes of geopolitical projects such as the European Union's Neighbourhood Policy Initiative which aims at regional partnerships but in so doing reduces the nature of neighbourhood to largely technocratic realms of policy interaction, sidelining already existing socio-cultural and economic networks that link the EU to its neighbours. At a more global level it is also quite clear that effective and equitable international cooperation, including empowered and inclusive forms of global governance, are the guarantee for the maintenance of viable national, 'sovereign' but above all humane borders. This implies that a major challenge will be to promote border sensitivities and cooperation architectures upon which a sense of shared responsibility for the global future can be developed.

\section{References}

Anzaldúa, G. E. (1987), Borderlands/La Frontera: The New Mestiza, San Francisco: Aunt Lute Books.

Awan, N. (2016), 'Introduction to border topologies', GeoHumanities, 2 (2), 279-283.

Benito, J. and A. Manzanas (eds) (2002), Literature and Ethnicity in the Cultural Borderlands, Leiden: Brill Rodopi.

Brambilla, C. (2015a), 'Exploring the critical potential of the Borderscapes concept', Geopolitics, 20 (1), 14-34.

Brambilla, C. (2015b), 'Navigating the Euro/African and migration nexus through the Borderscapes lens: Insights from the LampedusaInFestival', in C. Brambilla, J. Laine, J. W. Scott, and G. Bocchi (eds), Borderscaping: Imaginations and Practices of Border Making, Farnham: Ashgate, pp. 111-121.

Brambilla, C. and R. Jones (2020), 'Rethinking borders, violence, and conflict: From sovereign power to borderscapes as sites of struggles', Environment and Planning D: Society and Space, 38 (2), 287-305.

Brambilla, C. and H. Pötzsch (2015), 'Border, borderscapes, bordering', Society \& Space. https://societyandspace.org/2015/03/05/iborder-borderscapes-bordering-chiara -brambilla-and-holger-potzsch/.

Casas-Cortes, M., S. Cobarrubias and J. Pickles (2016), “Good neighbours make good fences": Seahorse operations, border externalization and extra-territoriality', European Urban and Regional Studies, 23 (3), 231-251.

Cooper, A. (2015), 'Where are Europe's new borders? Ontology, methodology and framing', Journal of Contemporary European Studies, 23 (4), 447-458.

De Certeau, M. (1990), L'invention du Quotidien. 1. Les arts de faire, Paris: Gallimard.

Dear, M. and G. Leclerc (eds) (2003), Post-Border City: Cultural Spaces of Bajalta California, London and New York: Routledge. 
Deiana, M. A., M. Komarova and C. McCall (2019), 'Cross-border cooperation as conflict transformation: Promises and limitations in EU peacebuilding', Geopolitics, 24 (3), 529-540.

Dell'Agnese E. and A. L. Amilhat Szary (2015), 'Introduction. Borderscapes: From border landscapes to border aesthetics', Geopolitics, 20 (4), 4-13.

Dijstelbloem, H. and L. van der Veer (2019), 'The multiple movements of the humanitarian border: The portable provision of care and control at the Aegean Islands', Journal of Borderlands Studies, DOI:10.1080/08865655.2019.1567371.

Ferrer-Gallardo, X., A. Albet-Mas and K. Espiñeira (2015), 'The borderscape of Punta Tarifa: Concurrent invisibilisation practices at Europe's ultimate peninsula', Cultural Geographies, 22 (3), 539-547.

Grundy-Warr, C. and P. K. Rajaram (eds) (2007), Borderscapes: Hidden Geographies and Politics at Territory's Edge, Minneapolis: University of Minnesota Press.

Günay, C. and N. Witjes (eds) (2017), Border Politics, Cham: Springer.

Haselsberger, B. (2014), 'Decoding borders. Appreciating border impacts on space and people', Planning Theory \& Practice, 15 (4), 505-526.

van Houtum H. and T. van Naerssen (2002), 'Bordering, ordering and othering', Tijdschrift Voor Economische En Sociale Geografie, 93 (2), 125-136.

Jones, R. and C. Johnson (2016), Placing the Border in Everyday Life, London and New York: Routledge.

Kallio, K. P., J. Häkli and E. Pascucci (2019), 'Refugeeness as political subjectivity: Experiencing the humanitarian border', Environment and Planning C: Politics and Space, 37 (7), 1258-1276.

Kolossov, V. (2006), 'Theoretical limology: Postmodern analytical approaches', Diogenes, 53 (2), 11-22.

Krasteva, A. (2020), 'If borders did not exist, Euroscepticism would have invented them or, on Post-Communist re/de/re/bordering in Bulgaria', Geopolitics, 25 (3), 678-705.

Kun, J. and F. Montezemolo (eds) (2012), Tijuana Dreaming: Life and Art at the Global Border, Durham, NC and London: Duke University Press.

Laine, J. (2016), 'The multiscalar production of borders', Geopolitics, 21 (3), 465-482.

Laine, J. P. and A. Casaglia (2017), 'Challenging borders: A critical perspective on the relationship between state, territory, citizenship and identity: Introduction', Europa Regional 24 (1/2), 3-8.

Longo, M. (2018), The Politics of Borders: Sovereignty, Security, and the Citizen after 9/11, Cambridge: Cambridge University Press.

Loong, S. (2019), 'The neoliberal borderscape: Neoliberalism's effects on the social worlds of migrants along the Thai-Myanmar border', Political Geography, 74, 102035.

Marsico, G. and A. Varzi (2015), 'Psychological and social borders: Regulating relationships', in J. Valsiner, G. Marsico, N. Chaudhary, T. Sato and V. Dazzani (eds), Psychology as a Science of Human Being, Berlin: Springer-Verlag, pp. 327-336.

McCall, C. (2014), The European Union and Peacebuilding: The Cross-Border Dimension, London: Palgrave Macmillan.

Medeiros, E. (ed.) (2018), European Territorial Cooperation: Theoretical and Empirical Approaches to the Process and Impacts of Cross-Border and Transnational Cooperation in Europe, Cham: Springer.

Mezzadra, S. and B. Neilson (2012), 'Between inclusion and exclusion: On the topology of global space and borders', Theory, Culture \& Society, 29 (4-5), 58-75.

Newman, D. (2003), 'On borders and power: A theoretical framework', Journal of Borderlands Studies, 18 (1), 13-25. 
Paasi, A. (1999), 'Boundaries as social practice and discourse: The Finnish-Russian border', Regional Studies, 33 (7), 669-680.

Paasi, A. (2012), 'Border studies reanimated: Going beyond the territorial/relational divide', Environment and Planning A, 44 (10), 2303-2309.

Pallister-Wilkins, P. (2017), 'Médecins avec frontières and the making of a humanitarian borderscape', Environment and Planning D: Society and Space, 36 (1), 114-138.

Parker, N. and N. Vaughan-Williams (2012), 'Critical border studies: Broadening and deepening the "lines in the sand" agenda', Geopolitics, 17 (4), 727-733.

Parker, N. and N. Vaughan-Williams et al. (2009), 'Lines in the sand? Towards an agenda for critical border studies', Geopolitics, 14 (3), 582-587.

Popescu, G. (2011), Bordering and Ordering the Twenty-First Century: Understanding Borders, Lanham, MD: Rowman \& Littlefield.

Rumford, C. (2006), 'Introduction: Theorizing borders', European Journal of Social Theory, 9 (2), 155-169.

Rumford, C. (2014), Cosmopolitan Borders, Basingstoke: Palgrave Macmillan.

Schimanski, J. H. (2019), 'Migratory angels: The political aesthetics of border trauma', in K. Horsti (ed.), The Politics of Public Memories of Forced Migration and Bordering in Europe, London: Palgrave Pivot, pp. 37-52.

Scott, J. W. (2018), 'Globalization and border studies', in R. C. Kloosterman, V. Mamadouh and P. Terhorst (eds), Handbook on the Geographies of Globalization, Cheltenham, UK and Northampton, MA, USA: Edward Elgar Publishing, pp. 62-82.

Sohn, C. (2016), 'Navigating borders' multiplicity: The critical potential of assemblage', Area, 48 (2), 183-189.

Staudt, K. (2017), Border Politics in a Global Era: Comparative Perspectives, Lanham, MD: Rowman \& Littlefield.

Tsoni, I. W. (2019), Affective Borderscapes: Constructing, Enacting and Contesting Borders Across the Southeastern Mediterranean (Dissertation series in Migration, Urbanisation, and Societal Change), Malmö: Malmö University.

Vallet, E. (ed.) (2018), Borders, Fences and Walls: State of Insecurity?, Abingdon: Routledge.

Vasilev, G. (2015), 'Open borders and the survival of national cultures', in L. Weber (ed.), Rethinking Border Control for a Globalizing World: A Preferred Future, London: Routledge, pp. 98-115.

Vaughan-Williams, N. (2009), Border Politics: The Limits of Sovereign Power, Edinburgh: Edinburgh University Press.

Vaughan-Williams, N. and M. Pisani (2020), 'Migrating borders, bordering lives: Everyday geographies of ontological security and insecurity in Malta', Social \& Cultural Geography, 21 (5), 651-673.

Velasco Ortiz, L. and F. Contreras (2014), 'The border as a life experience: Identities, asymmetry and border crossing between Mexico and the United States', Frontera Norte, 26 (3), 37-56.

Walters, W. (2015), 'Migration, vehicles, and politics: Three theses on viapolitics', European Journal of Social Theory, 18 (4), 469-488.

Wassenberg, B. and B. Reitel (eds) (2020), Critical Dictionary on Cross-Border Cooperation in Europe, Brussels: Peter Lang.

Wastl-Walter, D. (ed.) (2011), The Ashgate Research Companion to Border Studies, Farnham: Ashgate Publishing.

Wilson, T. and H. Donnan (eds) (2012), A Companion to Border Studies, Chichester: Wiley-Blackwell. 
Zeveleva, O. (2017), 'Biopolitics, borders, and refugee camps: Exercising sovereign power over non-members of the state', Nationalities Papers, 45 (1), 41-60.

Zúñiga, V. (1999), 'The changing face of border culture studies', NACLA Report on the Americas, 33 (3), 36-39. 